\title{
Reducing subsistence farmers' vulnerability to climate change: evaluating the potential contributions of agroforestry in western Kenya
}

\author{
Tannis Thorlakson ${ }^{1}$ and Henry Neufeldt ${ }^{2,3^{*}}$
}

\begin{abstract}
Subsistence farmers are among the people most vulnerable to current climate variability. Climate models predict that climate change will lead to warmer temperatures, increasing rainfall variability, and increasing severity and frequency of extreme weather events. Agroforestry, or the intentional use of trees in the cropping system, has been proposed by many development practitioners as a potential strategy to help farmers reduce their vulnerability to climate change. This study explores whether and, if so, how agroforestry techniques can help subsistence farmers reduce their vulnerability to climate change. From field research conducted in western Kenya, we find that households are not currently coping with climate-related hazards in a sustainable way. Farmers are aware of this, and believe that the most effective way to adapt to climate-related shocks is through improving their general standard of living. We evaluated agroforestry as one possible means of improving farmers' well-being. By comparing farmers engaged in an agroforestry project with a control group of neighboring farmers, we find that involvement in agroforestry improves household's general standard of living via improvements in farm productivity, off-farm incomes, wealth and the environmental conditions of their farm. We conclude that agroforestry techniques can be used as an effective part of a broader development strategy to help subsistence farmers reduce their vulnerability to climate-related hazards.
\end{abstract}

Keywords: Africa, Agroforestry, Climate change adaptation, Food security, Smallholder development, Vulnerability

\section{Introduction}

Climate models predict that climate change will lead to, among other things, an increase in unpredictability of rainfall, warmer temperatures, and an increase in the severity and frequency of extreme weather events [1]. These changes are expected to decrease agricultural productivity in the developing world by $10 \%$ to $20 \%$ over the next 40 years [2]. Subsistence farmers in the developing world find it particularly difficult to cope with such climaterelated hazards, as they do not have the capital to invest in new adaptive practices with which to protect their homes and families [3]. Especially sensitive to climatic changes are those households that rely almost entirely on rain-fed agriculture for their livelihoods. There has been a recent

\footnotetext{
* Correspondence: H.Neufeldt@cgiar.org

${ }^{2}$ World Agroforestry Centre (ICRAF), Nairobi, Kenya

${ }^{3}$ CGIAR Research Program on Climate Change, Agriculture and Food Security (CCAFS)

Full list of author information is available at the end of the article
}

focus in the international development community and literature on strategies to help subsistence farmers reduce their vulnerability to climate change $[4,5]$.

How communities cope with exposure to current climate-related shocks and stresses can give us insight into their ability to deal with future variability brought on by climate change [6]. Scholars are calling for a more interdisciplinary combination of academic fields and farmer perceptions to understand the effects of climate-related hazards on the complex systems of rural farmers [3,5,7].

Agroforestry has been proposed as one potential strategy for helping subsistence farmers reduce their vulnerability to climate change [8-10]. Research suggests that agroforestry improves farmer well-being through improving farm productivity and incomes $[9,11,12]$. Yet there are few studies that explicitly examine how agroforestry techniques can reduce vulnerability to climate change [13].

In addition, many agroforestry analyses assess the impacts of scientist-managed agroforestry plots, while

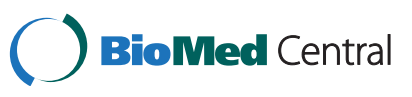


relatively few studies analyze existing farmer-managed agroforestry development projects [14]. Farmer-managed agroforestry projects allow farmers to choose the type of agroforestry techniques to employ and rely on farmers to modify the techniques to match their needs. Farmermanaged projects therefore more accurately represent how agroforestry techniques are used under normal circumstances. There is a need for more extensive analyses of these types of projects [14].

To address the knowledge gaps outlined above, we set out to evaluate whether, and, if so how, farmer-managed agroforestry projects reduce farmers' vulnerability to climate change. We use Turner et al.'s vulnerability framework to understand farmer vulnerability [15]. Turner et al. divide a system's vulnerability into three major components: exposure, sensitivity and resilience [15]. Exposure considers the frequency, magnitude and duration to which a system is subject to hazards. We use the term 'climate-related hazards' to cover both climate-related shocks, such as floods and droughts, and longer-term climate stresses, such as increasing rainfall variability. The sensitivity of a system is determined by both the environmental and human characteristics that contribute to how a system responds to exposures. Finally, the resilience of a system refers to actions that can improve a system's ability to cope with outside hazards.

We began our study by assessing farmers' sensitivity to climate-related hazards through examining how farmers are currently coping with floods, droughts and rainfall variability. We then sought to understand what farmers believe to be the most effective way to become more resilient in the face of these outside stresses. From our findings, we established criteria to assess if agroforestry can be an effective technique to help reduce vulnerability to climate-related hazards. In short, this study sets out to investigate three major questions: How are farmers currently coping with exposure to climate-related hazards? What do farmers believe to be the most effective method to improving their resilience? And finally, how do agroforestry practices help farmers adapt to exposure to climate-related hazards?

To address these questions, we undertook a field study of a farmer-managed agroforestry development project in the Nyando District in western Kenya. We compare farmers who have been involved in World Agroforestry Centre (ICRAF) agroforestry development projects for 2 to 4 years to neighboring farmers with no agroforestry training. We used household surveys, in-depth interviews and focus group discussions to provide both a qualitative and a quantitative dimension to our analysis.

\section{Methods}

We used a mixed methods approach that combined household surveys, in-depth interviews, focus group discussions and field observations to investigate our research questions. We used interviews and participatory activities to understand how climate-related hazards are currently impacting farmers' well-being and how farmers conceptualize their well-being. These discussions generated a list of key indicators that farmers feel are most important to the well-being of their households. Finally, the household surveys allowed us to quantify how farmer-managed agroforestry interventions impacted farmers' well-being in the face of climate-related hazards. This type of mixed method approach has been strongly encouraged in the literature to better capture the reality on the ground [16].

\section{Site}

We conducted research in two sublocations of the Nyando District (Nyanza Province) of western Kenya. The Lower Nyando sublocation is characterized by low productivity, erratic rainfall and severe soil erosion. Elevation is $1,200 \mathrm{~m}$ with an average annual rainfall of $1,000 \mathrm{~mm}$ [17]. This area is predominantly of the Luo tribe. The Middle Nyando sublocation has higher productivity, cooler temperatures and more equitably distributed rainfall. Average elevation is 1,600 meters with average rainfall of $1,500 \mathrm{~mm}$ per year [17]. Middle Nyando has a mix of Luo and Kalinjin tribes. Maize is the staple crop in both sublocations, with sugar cane and coffee also grown as cash crops in Middle Nyando.

\section{Project background}

Seven community groups in Lower and Middle Nyando were provided tree seedlings and agroforestry training by ICRAF in 2006 and 2008. All members of these groups were included in the treatment group. Households within the treatment group received: 5 agroforestry and agriculture training sessions, 200 to 300 seedlings, training in tree nursery management, tools and seedlings for tree nursery establishment, a small amount of food each week for involvement in community projects, and ICRAF staff support for 1 year, roughly a US $\$ 300$ investment per household. ICRAF provided a mix of tree species to farmers, including: Acacia mellifera and Acacia polyacantha, Albizia coriaria, Calliandra calothyrsus, Casuarina equisetifolia, Cordia abyssinica, Faidherbia albida, Gliricidia sepium, Grevillea robusta, Markhamia lutea, Senna siamea, and Warburgia ugandensis. Two additional community groups were selected as the control group based on their proximity to the treatment groups. None of the farmers in the control group had participated in agroforestry training in the past.

Due to the distinct climatic differences between Lower and Middle Nyando, it is difficult to compare groups across sublocations. In addition, farmers in the two sublocations differ in ethnicity, market access, land size and 
other key characteristics. Treatment and control households within sublocations are fairly similar, as can been seen across the basic household variables presented in Table 1. A t-test for differences of means was carried out to assess differences between all treatment and control groups and unless noted in the table, no significant differences were observed. Despite similarities in basic household characteristics, it is important to note that the control and treated households were located 1 to $2 \mathrm{~km}$ apart.

\section{Data collection}

We surveyed 119 households in June and July 2010 to capture basic household characteristics, agroforestry practices used and biophysical farm observations. Three households were removed from the dataset due to their extreme differences across key household parameters listed in Table 1. We conducted 20 in-depth interviews with 13 farmers (6 women), 4 village elders ( 1 woman) and 3 community leaders (all men). In addition, we held seven interactive focus group discussions with agriculture-oriented community groups. Questions focused on observed changes in climate, farming practices productivity constraints, agroforestry practices, future goals and how households had coped with the most recent floods and droughts. Men and women were split into subgroups for a part of each focus group discussion. Detailed methodology is presented in Thorlakson [18].

Key variables used for statistical analysis were measured in a way consistent with the literature in the field. We used an estimate of total livestock value as a proxy for household wealth, as livestock is the most frequently cited indicator of farmer wealth among the Luo and Kalinjin tribes of western Kenya [19]. We collected other indicators of wealth (housing material, type of roof, and so on) but found little variation among these indicators across households in our sample. Livestock holdings were converted into an economic value using current local market prices. We measured farm productivity by converting current seasonal crop production to economic units using average 2010 crop prices in the region. Soil erosion intensity was measured on a nine- point scale using two on-farm observations, type of erosion present and intensity of observed erosion [20]. We estimated total above ground tree biomass using Kuyah et al.'s allometric equation 1 and corresponding coefficients, which were derived from a neighboring area in western Kenya with similar growing conditions [21].

\section{Statistical data analysis}

To assess the impacts of the agroforestry development project on farmer well-being we used household wealth and farm productivity as dependent variables. We used matching techniques to increase the similarities between the treatment and control groups [22,23]. Matching gives additional weight to households across treatment groups that are most similar on selected parameters. Parameters used for matching included: household size, land tenure, household head educational level, soil type and gender of household head, as these measures were all noted in the literature to affect subsistence farmer well-being [24].

Using the matched data, linear regressions were used to evaluate the treatment's impact on the outcome variables, accounting for potential regional differences and treatment effects across the two sublocations [25]. This analysis method was validated after incorporating the basic household parameters into the regression as well, achieving similar results.

\section{Qualitative data analysis}

We transcribed all field observations, interview notes and focus group discussion notes, and tagged major topics and keywords. This allowed us to compare farmers' views on key themes across different treatment groups, locations and household characteristics [26]. Common themes that emerged included agroforestry use, climate change, drought, farm constraints, farming techniques, floods, labor, erosion, rainfall change and well being.

\section{Results}

\section{Climate change}

In 2010, the Nyando District provided a unique opportunity to study the impact of climate-related hazards on farmers, as both a drought and a flood had recently

Table 1 Mean (SD) for key household parameters

\begin{tabular}{|c|c|c|c|c|c|}
\hline & \multicolumn{2}{|c|}{ Lower Nyando } & \multicolumn{2}{|c|}{ Middle Nyando } & \multirow[t]{2}{*}{ All data } \\
\hline & Treated & Control & Treated & Control & \\
\hline Household size & $6.7(2.7)$ & $6.4(2.7)$ & $6.2(3.3)$ & $7.2(2.0)$ & $6.7(2.7)$ \\
\hline Household head sex ( $1=$ male $)$ & $0.61(0.49)$ & $0.6(0.51)$ & $0.93(0.25)$ & $0.93(0.26)$ & $0.77(0.43)$ \\
\hline Education of household head (form, 0 to 16 ) & $5.4(4.6)$ & $4.2(4.9)$ & $7.2(3.5)$ & $6.1(4.2)$ & $5.9(4.3)$ \\
\hline Land size (hectares) & $0.97^{*}(0.38)$ & $0.69(0.32)$ & $1.46(1.38)$ & $1.42(1.3)$ & $1.2(1.1)$ \\
\hline Holds title to Land? ( $1=$ yes $)$ & $0.91 *(0.23)$ & $1(0)$ & $0.63(0.49)$ & $0.60(0.50)$ & $0.80(0.42)$ \\
\hline $\bar{N}$ & 46 & 15 & 30 & 28 & 119 \\
\hline
\end{tabular}

*Mean values are significantly different from control group households at the $5 \%$ level. 
affected the area. Lower and Middle Nyando experienced drought-like conditions in September and October 2009 when the short-rains season failed. Specific data on the intensity of the drought in this region is sparse, but food shortage was widespread in the region due to water shortages [27]. In addition, the Lower Nyando region was also hit with a significant flood in March and April of 2010 that displaced 180 people and destroyed 7 homes across the Nyando District [28].

Farmers interviewed grouped climate-related hazards into three major topics: increased variability of the timing of rains, droughts, and floods. We focus on these three major types of hazards, though we understand that other changes are also expected to occur due to climate change.

\section{Impacts due to exposure to climate-related hazards}

Results from household surveys show that farmers' farm productivity decreased by $60 \%$ and $39 \%$ in Lower and Middle Nyando respectively during the 2009 to 2010 growing season in comparison to a typical growing season as experienced in 2008 to 2009. Farmers attribute this decrease to a combination of the drought, flood and rain variability experienced in the previous 12 months. Maize, the staple crop in the region, followed similar production trends (Table 2).

Due to the climate-related hazards experienced in the 2009 to 2010 season, households reported experiencing intense periods of hunger. $100 \%$ and $70 \%$ of households in the Lower and Middle Nyando region, respectively, experienced at least 1 additional month of hunger as compared to a typical year. Average duration of hunger periods for households were 4.5 and 2.3 months in Lower and Middle Nyando, respectively. A hunger period, as defined by farmers, is a time when the household had severe difficulties obtaining enough food to feed all household members.

\section{Coping strategies during exposure to climate-related hazards}

During periods of hunger, the most common coping strategy reported was to reduce food consumption through restricting the size, diversity and number of meals taken each day. Households that were involved in off-farm activities intensified their work in these areas and others engaged in casual farm labor. Selling of livestock during drought and flood periods was a popular coping strategy, with $55 \%$ of farmers selling livestock in 2009 to 2010 to deal with food shortage. Consequently, livestock prices dropped $25 \%$ to $50 \%$ during this period. See Table 3 for a list of common coping strategies.

Farmers were also forced to use more detrimental coping strategies to cope with the reduced productivity in 2009 to 2010. From discussions with farmers, we defined detrimental coping strategies as those that have harmful long-term impacts on household productivity. Farmers reported selling oxen reserved for plowing during periods of drought, leading to lower farm productivity the following season as people then had to plow by hand. In all, $66 \%$ of farmers reported consuming seeds reserved for planting. This consumption had negative repercussions, as many farmers were forced to plant fewer seeds the following season due to the depletion of their personal seed stores and constraints in capital. In Middle Nyando, limited capital following the drought also restricted farmers' ability to purchase fertilizer and other chemical inputs regularly used. Some Middle Nyando farmers reported being forced to lease part of their farms for 2 years to wealthy farmers in the area in order to feed their families. This coping mechanism is especially detrimental as it prevents farmers from accessing their main source of livelihood, their land, for 2 years. According to some farmers, engaging in casual labor during periods of hunger also represents a detrimental coping strategy as it delays the planting in their own farms.

Farmers involved in an agroforestry development project typically used fewer detrimental coping strategies during hunger periods. Farmers with mature trees on their land were able to sell seedlings, timber and firewood and consume fruit from their trees during periods of hunger. Farmers reported that this diversification of coping strategies allowed them to rely less on other traditional coping strategies. See Table 3 for a comparison across groups.

\section{Adaptation to climate-related hazards}

The most effective way farmers found to reduce their vulnerability to these climate-related hazards was to

Table 2 Farm productivity and maize production during the 2009 to 2010 flood and drought year compared to an average year (2008 to 2009)

\begin{tabular}{|c|c|c|c|c|c|c|}
\hline & $\begin{array}{l}2009 \text { to } 2010 \text { farm } \\
\text { productivity (Ksh) }\end{array}$ & $\begin{array}{l}\text { Normal year farm } \\
\text { productivity (Ksh) }\end{array}$ & $\begin{array}{l}\text { Percentage } \\
\text { difference }\end{array}$ & $\begin{array}{l}\text { Maize production } \\
2009 \text { to } 2010(\mathrm{~kg})\end{array}$ & $\begin{array}{l}\text { Normal year maize } \\
\text { production }(\mathrm{kg})\end{array}$ & $\begin{array}{l}\text { Percentage } \\
\text { difference }\end{array}$ \\
\hline $\begin{array}{l}\text { Lower } \\
\text { Nyando }\end{array}$ & 8,200 & 20,500 & $-60 \%$ & 85 & 220 & $-61 \%$ \\
\hline $\begin{array}{l}\text { Middle } \\
\text { Nyando* }\end{array}$ & 43,000 & 70,500 & $-39 \%$ & 900 & 1,300 & $-30 \%$ \\
\hline
\end{tabular}


Table 3 Proportion of farmers using coping strategies to deal with flood and drought in 2009 to 2010

\begin{tabular}{lllll}
\hline & \multicolumn{2}{l}{ Lower Nyando } & & Middle Nyando \\
\cline { 2 - 5 } & Treated (\%) & Control (\%) & Treated (\%) & Control (\%) \\
\hline Reduce quantity, quality or no. of meals & 82 & 66 & 54 & 26 \\
\hline Help from government, NGO, church & 40 & 47 & 29 & 41 \\
\hline Borrow money & 31 & 40 & 32 & 18 \\
\hline Casual labor & 24 & 40 & 36 & 43 \\
\hline Sell possessions or livestock & 73 & 66 & 50 & 71 \\
\hline Consume seeds & 67 & 80 & 68 & 38 \\
\hline Consume or sell fruit from trees & 40 & 25 & 28 & 28 \\
\hline$N$ & 45 & 15 & &
\end{tabular}

diversify income to include off-farm activities. Farmers who engaged in off-farm activities, such as wage-earning jobs or owning small shops, reported being better able to cope with climate-related hazards than their farming neighbors. Farmers with higher average farm productivity also reported fairing better during rainfall variations as they had more stores to draw on when current production was low.

\section{Well-being}

We discussed with farmers how they believed they could improve their overall standard of living when exposed to the hazards described above.

\section{Importance of food security}

Farmers interviewed were most interested in ways to improve their household's food security, especially during periods of outside shocks. Food security, as defined by farmers, is the ability to obtain an adequate diet for all household members throughout the year, without being forced to use long-term savings to purchase food. To achieve food security, farmers reported being interested in opportunities to start small business ventures or obtaining credit to purchase farm implements to improve their farm productivity. Farmers also expressed interest in opportunities to improve their agricultural knowledge and to learn about alternative income opportunities as other indirect pathways to improve food security.

Our quantitative analyses support farmers' assertion that farm productivity is tied to food security. Controlling for other key variables, our findings show that a household in the 75th percentile of farm productivity is on average $11 \%$ more food secure than a similar household in the 25th percentile of farm productivity $(P<0.0001)$.

\section{Other components of well-being}

It is only after a household reaches relatively food security that they begin investing in long-term processes for improving other components of their well-being. This stepwise process to improving well-being became clear when contrasting Lower and Middle Nyando farmers' goals. Lower Nyando farmers are still very food insecure and thus rarely report focusing on any goals not directly related to improving their household's food supply. However, some Middle Nyando farmers report feeling food secure throughout the year and discuss goals related to expanding landholdings, improving their children's education and investing in long-term projects to ensure financial security.

Farmers also reported that they have begun to put more emphasis on the environmental conservation of their land. Both treatment and control focus groups concluded that their well-being had significantly declined due to soil erosion on their farms. As one farmer explained, 'Soil is our livelihood'. A number of community groups had recently been formed to focus on environmental issues and soil conservation practices in the area, suggesting that environmental conservation is perceived as a key way through which communities believe they can improve their well-being.

Constraints to achieving well-being are summarized in Table 4. Most farmers agreed that unpredictable weather and lack of access to capital are the two largest constraints to improving their lives, but environmental degradation was also cited as a major concern.

\section{Vulnerability reduction}

In addition to food security, most farmers also cited an ability to cope with shocks and stresses as a key characteristic of a successful household. During times of stress, successful households are food secure for 2 to 3 months longer, often giving support to their neighbors and family. Successful households are not forced to sell livestock or belongings, take their children out of school, or significantly reduce meal portions during exposure to outside shocks.

Farmer concerns about their household's vulnerability to outside shocks was evident in almost all interviews. As one farmer explained, 'We are reliant on the rains 
Table 4 Major constraints farmers identified to achieving well-being

\begin{tabular}{|c|c|c|c|c|c|}
\hline & \multicolumn{2}{|c|}{ Lower Nyando } & \multicolumn{2}{|c|}{ Middle Nyando } & \multirow{2}{*}{$\begin{array}{l}\text { All } \\
\text { data } \\
\text { (\%) }\end{array}$} \\
\hline & Treated (\%) & Control (\%) & Treated (\%) & Control (\%) & \\
\hline Weather & 66 & 80 & 86 & 92 & 73 \\
\hline Capital & 59 & 73 & 64 & 86 & 68 \\
\hline Farm inputs and implements & 39 & 46 & 40 & 43 & 41 \\
\hline Environmental health of land & 52 & 66 & 24 & 80 & 53 \\
\hline Health of household & 25 & 26 & 43 & 57 & 36 \\
\hline $\mathrm{N}$ & 45 & 15 & 28 & 28 & 116 \\
\hline
\end{tabular}

from God, and there is nothing we can do to change these patterns'. Currently, households feel unable to deal with the unexpected problems that arise from extreme weather events, sicknesses, job loss, low cash crop market prices, and so on. Farmers continuously reiterated their need to find better ways in which to deal with exposure to outside shocks, particularly rainfall variability and drought, which frequently disrupt their lives. Farmers were most interested in improving their off-farm incomes, diversifying income sources and improving general farm productivity to reduce their sensitivity to climate-related hazards.

During interviews, farmers also emphasized their desire to remain autonomous in deciding what type of specific adaptation measures they choose to employ. Many farmers complained that some specific climate-change adaptation measures suggested by agricultural extension workers or non-profit organizations, such as planting droughtresistant maize, were actually detrimental to their farm yields during normal or heavy rains. With the uncertainties farmers face in weather patterns from year to year, they were unwilling to invest in strategies that were less productive under certain weather conditions. Farmers reported being interested in receiving information and advice on potential adaptation strategies, as long as outside constituents did not decide what activities would take place in their communities without their consent.

\section{Agroforestry}

Using our results that farmers were most interested in general well-being improvements to adapt to climaterelated hazards, we assessed agroforestry's potential in providing these general well-being improvements in the face of climate-related hazards. When interpreting these results, it is important to note that the agroforestry project assessed has only been in operation for 2 to 4 years and thus the long-term effects of agroforestry involvement are not captured in our analysis.

\section{Improvements in farm productivity}

Our results suggest that agroforestry improves farm productivity and household wealth. $43 \%$ of farmers noticed an improvement in farm productivity after planting trees on their land. Farmers found trees improved their farm productivity by decreasing soil erosion and increasing soil fertility. Farmers who reported no change in farm productivity explained either they had not planted nitrogen-fixing trees in their fields or the trees were not yet mature enough to assess the effects.

Overall, only $12 \%$ of farmers in the agroforestry program chose to intercrop nitrogen-fixing trees in their fields. Many farmers expressed concern that planting trees in their fields would reduce productivity of their crops and were unwilling to take such a risk. All farmers who have begun intercropping trees reported significant improvements to their productivity after incorporating nitrogen rich leaves into their soil.

For farms using agroforestry techniques, our quantitative data suggests a slight improvement in farm yields in both Lower and Middle Nyando when compared with the control group. Our linear regression model estimates that Lower Nyando farmers involved in an agroforestry project improved their farm productivity, on average, by about 1,500 Ksh (US\$19) per year when compared to the control group. (For all currency conversion, the July 2010 current rate of $80 \mathrm{Ksh}=\mathrm{US} \$ 1$ was used.) A 1,500 Ksh increase is the equivalent of increasing an average Lower Nyando household's maize yields by $35 \%$. However, the standard errors in this analysis are quite large $(P=0.678)$ (Table 5). In Middle Nyando, the results from statistical analysis show farm productivity increase by 2,100 Ksh (US\$26) for treated units but again with a high standard error $(P=0.549)$. This increase is equivalent to improving an average Middle Nyando household's maize yields by $20 \%$. The high uncertainty in the quantitative results of the study was likely in part due to the small sample size, short duration of agroforestry participation and the non-randomized selection of households.

\section{Improvements in household wealth and income diversity}

Overall, farmers were most interested in trees' ability to provide them with additional farm income. During focus group discussions, farmers ranked the potential income 
Table 5 Agroforestry's effect on farm productivity and household wealth

\begin{tabular}{|c|c|c|c|c|c|c|}
\hline & \multicolumn{3}{|c|}{ Lower Nyando } & \multicolumn{3}{|c|}{ Middle Nyando } \\
\hline & Treated & Control & Difference & Treated & Control & Difference \\
\hline Farm Productivity (Ksh) & 4,600 & 3,100 & 1,500 & 16,200 & 14,100 & 2,100 \\
\hline SD & & & 3,700 & & & 3,400 \\
\hline$P$ value & & & 0.68 & & & 0.55 \\
\hline Household Wealth (Ksh) & 62,200 & 38,400 & 23,800 & 58,900 & 67,300 & $-8,400$ \\
\hline SD & & & 13,900 & & & 12,900 \\
\hline$P$ value & & & 0.09 & & & 0.516 \\
\hline $\mathrm{N}$ & 45 & 15 & & 28 & 28 & \\
\hline
\end{tabular}

Values from linear regression models run on matched data.

benefits from trees as the most helpful aspect of the trees on their land. The excitement farmers expressed in the income benefits from tree products stemmed in part from the limited opportunities for income generation in the area. As one elder farmer explained, 'There is just no way to earn an income here... No one has money to buy anything from anyone else'.

Among the farmers in Lower Nyando who have had trees for 4 years, $87.5 \%$ of farmers reported income improvements. Benefits were reported from the sale of fuel wood, timber, fruit and seedlings and through savings in food purchases due to an increase in farm productivity. For those farmers with mature fruit trees, average seasonal profits were 3,250 Ksh (US\$40). Farmers who had not seen improvement in their income after planting trees explained that their trees were still too young to provide any benefits.

In our quantitative analysis we used livestock holding as a surrogate for household income as it is difficult to measure wealth in real terms among small-scale farmers. Household wealth, as measured by current livestock holdings, improved for Lower Nyando participants involved in an agroforestry project. Treated units in Lower Nyando had livestock holdings worth 24,000 Ksh (US\$300) more than control units in the region, on average $(P=0.092$, Table 5$)$. The Lower Nyando statistical findings agree with our qualitative observations about agroforestry's ability to improve household wealth.

For Middle Nyando, project involvement decreased average value of livestock holdings by $8,000 \mathrm{Ksh}$ (US $\$ 100)$, $(P=0.516$, Table 5). It is not surprising that Middle Nyando farmers have not improved their wealth through agroforestry involvement, as these farmers planted their trees only 2 years ago and do not yet have mature trees that can provide timber, fruit or fuel wood for sale. Due to their remote location, Middle Nyando farmers have also had less success selling tree seedlings to neighboring communities so have been unable to receive substantial income benefits from this source. Lower Nyando farmers, however, reported selling fruit, timber, fuel wood and seedlings on a regular basis to local markets. From discussions with farmers in the area, it appears that the inconclusive results on wealth in Middle Nyando are in part due to a lack of infrastructure in the area, that is currently acting as a barrier to access markets for their tree crops.

\section{Other benefits}

Involvement in agroforestry practices also provides a number of other general improvements that helped farmers increase the environmental sustainability of their farms. In all, $70 \%$ of farmers involved in agroforestry projects cited soil erosion control as a key benefit. Soil erosion was particularly detrimental to people affected by the 2010 floods in Lower Nyando, with many farmers complaining of decreased soil fertility due to the intense soil erosion during the heavy rains. Farmers considered tree planting to be the most effective method of soil erosion control.

Our field observations support farmers' claims that increased tree density reduces soil erosion. As can be seen in Figure 1, the data show a downward trend when the tree biomass per hectare is plotted against a scale of soil erosion observed, showing that, on average, farmers with higher tree biomass per hectare experience less soil erosion (correlation coefficient $=-0.31$ ).

Involvement in agroforestry also provides substantial labor savings to women household members by reducing time spent on fuel wood collection. Some women reported walking over $20 \mathrm{~km}$ to purchase fuel wood in neighboring districts. Women in low-tree-density areas also reported being threatened by their neighbors in a struggle over fuel wood resources.

Our research shows that agroforestry involvement leads to substantial reductions in fuel wood purchased and the time that households use to collect fuel wood (Table 6). Fuel wood was the second most commonly cited use of trees on the farm. Women with mature trees on their land felt that they now have access to a safer and more stable supply of fuel wood. These women reported devoting 


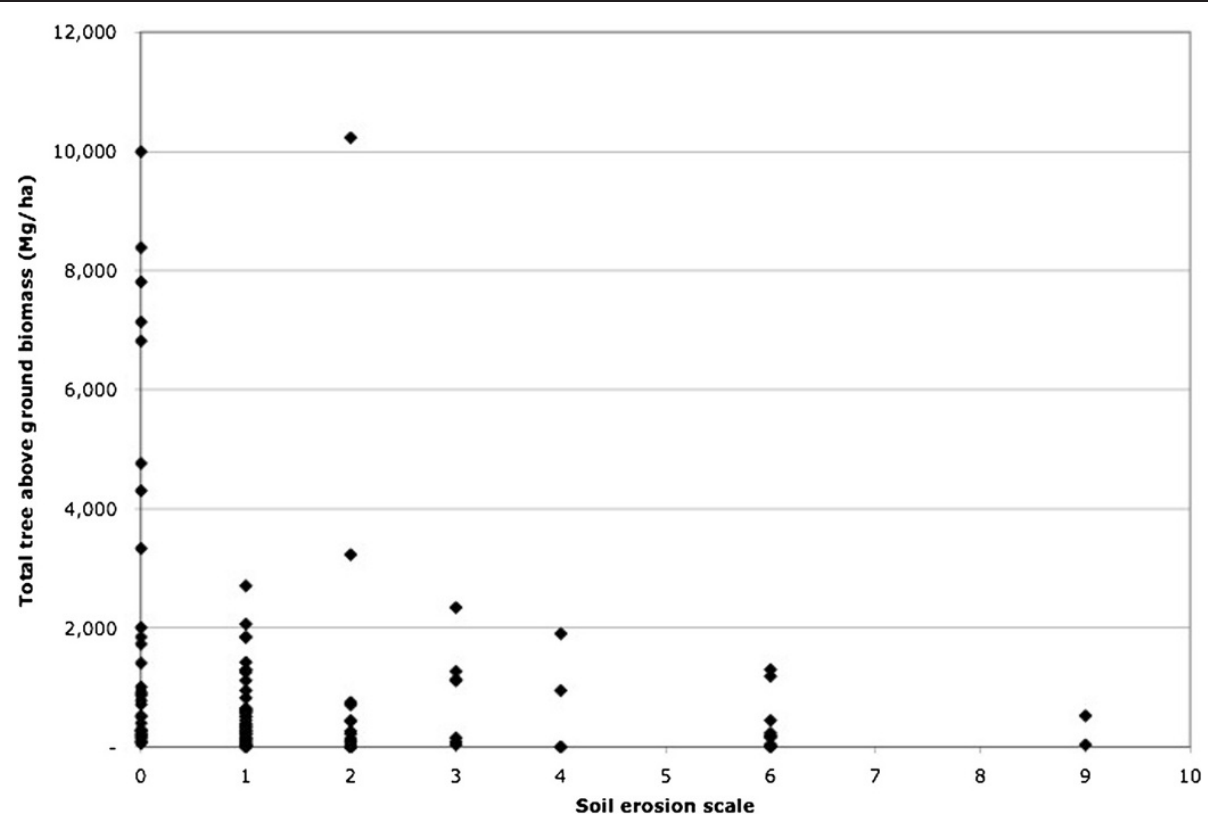

Figure $1 \mathrm{Scale}$ of soil erosion plotted against total above ground tree biomass per hectare $(\mathbf{M g} / \mathbf{h a})$. Tree biomass was estimated using Kuyah et al.'s equation number 1 [21].

more time to income-generating activities and farm care now that fuel wood stocks are nearby.

It also appears that there is an opportunity in lowtree-density areas to increase off-farm incomes of women through local fuel wood sales. There is a substantial demand for purchased fuel wood in these areas, yet only two farmers reported having enough excess fuel wood on their land to sell fuel wood at the market.

\section{Specific coping strategies}

In addition to the general benefits listed above, agroforestry also provides specific coping options to farmers during exposure to floods and droughts. Some farmers reported having fruit from their trees as their only steady source of sustenance during the floods, as other crops were underwater or had been washed away. During the drought, many farmers reported selling fuel wood and timber to produce additional income for food purchases. Tree roots prevented extensive soil erosion and ensuing soil fertility loss for farmers in Lower Nyando during the 2010 floods. The alternate coping strategies provided by trees allowed farmers additional flexibility in their management of the climate stresses they faced.

\section{Discussion}

Achieving well-being or a similarly acceptable quality of life is a fundamental goal in most development projects focused on poverty alleviation [29]. Our findings also showed that farmers expressed an interest in improving their well-being, but with a particular emphasis on the need to reduce vulnerability when exposed to outside shocks and stresses. This finding agrees with those of Place et al. and encourages a move away from the focus only on poverty alleviation to focus on the reduction of the vulnerability of poor populations [16].

Using these ideas expressed by farmers, we modified, for the use of our analysis, the definitions of well-being discussed in the literature [30-32]. We define well-being as the ability to improve one's household income, assets, and food security in the face of outside stresses and shocks (modified from 30,31). This definition is unique because it takes into account the need to achieve wellbeing improvements while exposed to climate-related hazards and it specifically stresses the importance of food security and other tangible changes.

We found that food security is a concept very important to the farmers interviewed but it is not always

Table 6 Fuel wood acquisition

\begin{tabular}{|c|c|c|c|c|c|c|}
\hline & \multicolumn{3}{|c|}{ Lower Nyando } & \multicolumn{3}{|c|}{ Middle Nyando } \\
\hline & Treated & Control & Difference & Treated & Control & Difference \\
\hline Weekly time spent on fuel wood collection (min) & 360 & 540 & 180 & 220 & 260 & 40 \\
\hline Percentage of households purchasing fuel wood & $17 \%$ & $66 \%$ & & $3 \%$ & $7 \%$ & \\
\hline $\mathrm{N}$ & 45 & 15 & & 28 & 28 & \\
\hline
\end{tabular}


emphasized in the literature's definitions of well-being. Food insecure farmers in Lower Nyando explained that all of their long-term decisions were dependent on their food supply. These farmers were forced to stop longterm projects, including the care of their seedlings, when faced with the significant food shortage during the 2009 to 2010 season. In contrast, farmers in Middle Nyando, where average hunger periods were less severe, felt much better equipped to plan and save for their futures. This contrast between how farmers in Lower and Middle Nyando think about long-term goals supports Appadurai's conclusion that more marginalized groups have a more limited ability to aspire [33]. It also supports evidence that food insecure farmers tend to be less innovative. This has recently been shown in a representative survey of 700 farmer households in four countries in East Africa [34].

Farmers' emphasis on food security should provide a reminder to development academics of the importance of dealing with basic necessities when considering more complex development interventions. It is paramount that development projects operating in food-insecure areas show how they can help households improve their food security from the outset. This lesson is especially relevant to agroforestry development projects, as farmers are asked to invest substantial time in tree seedling care before any benefits are accrued. For households that are still struggling to ensure they have enough to eat, tree seedlings and other long-term investments are often neglected until this need is met.

The impacts of the recent floods, droughts and rainfall variability on farmers are consistent with much of the literature of similar climate-related hazards in the area [35]. The literature on coping strategies also highlights similar strategies to those used by farmers in this study [36]. However, from our analysis it is clear that the current use of these traditional coping strategies will not be able to sustain households in the face of more frequent exposure to climate-related hazards predicted by climate change models such as Nelson et al.'s [37]. Already, farmers experience intense periods of food insecurity and are forced to engage in detrimental coping strategies that threaten the long-term sustainability of their farms and households' well-being. This finding is consistent with other analyses of the ability of subsistence farmers to cope with climate variability in the region [4].

The literature exhibits some tension on whether to focus climate change adaptation on these specific adaptation strategies or on the more general well-being improvements [38,39]. Through our discussions with farmers on future adaptation options, farmers largely agree with the literature that supports general well-being improvements to deal with future climate-related hazards [37,40-42]. Specifically, farmers are interested in improving their off-farm incomes and farm productivity. As climate change predictions continue to be highly unpredictable, it is important to focus on adaptation strategies that are robust and help ensure farmers' well-being under a variety of forms of climate-related hazards.

Farmers report, and the literature agrees, that some specific adaptation strategies, such as the current forms of drought-resistant crops, may actually increase farmers' vulnerability under certain climate-related hazards [41]. Farmers interviewed refused to use more drought-tolerant types of maize, as they could not afford the loss of productivity associated with these strains if the rains did come. These results highlight the need to do place-based studies of adaptive strategies to assess which specific projects will be most effective at reducing farmer vulnerability under a wide variety of climate hazards. Through our analysis, it appears that agroforestry can be an effective adaptation strategy, as agroforestry was shown to be beneficial under a wide range of climatic conditions. This interpretation also provides evidence for the introduction of financial safety networks, such as index insurances, as a means of reducing climate risk while allowing farmers to continue using improved seedling material for higher yields under normal climatic conditions. The index insurance could help farmers cope with greater losses during weather extremes such as droughts.

Farmers also expressed a strong desire to remain autonomous in making decisions about the implementation of climate-change adaptation strategies. However, it was also clear that households will need, and are interested in receiving, information and advice on potential climatechange adaptation strategies. This distinction between outside organizations' role as an advisor on adaptation options and an implementer of specific strategies is somewhat nuanced, but will be important to ensure farmer buy-in to future adaptation strategies. Adger et al. highlight the need to facilitate climate-change adaptation decisions among households, as individual autonomy alone does not necessarily lead to the most effective decisions [43]. Future research is needed to find effective advising strategies that can help farmers access information on and capital to invest in adaptation strategies.

Our findings provide quantitative results, supported and nuanced by qualitative descriptions, on how agroforestry techniques can help farmers mitigate their vulnerability to climate-related hazards, both through improving general well-being and through providing specific coping measures that are effective in the face of a wide range of climate-related hazards.

Despite the high standard errors within our quantitative analysis, in conjunction with our qualitative findings they suggest a positive correlation between agroforestry 
involvement and farm productivity and household wealth, similar to other literature in the field [44]. It is unsurprising that we observed only a small improvement in farm productivity because few farmers used intensive agroforestry techniques in their fields. Intercropping of nitrogen-fixing trees had low adoption among farmers because farmers considered planting trees in their field as risky. Planting trees along household boundaries appears to show greater acceptability among farmers and may be a good first step to integrate agroforestry practices into farms without the perceived risk of intercropping.

Improvements in household wealth were also limited due to the maturity of the trees. Most income comes from selling fruit, excess fuel wood and timber, and many farmers interviewed had only a limited number of mature trees on their land at the time of the survey. Limited improvements are therefore expected among the farmers who have only been using agroforestry techniques for 2 to 4 years. In addition, we feel that using livestock as a surrogate for household wealth did not capture the full change in farmers' wealth due to agroforestry practices. Future studies should consider a more robust measurement of wealth among subsistence farmers.

Our findings also highlight the length of time it takes for agroforestry practices to benefit farmers, as many of the impacts reported were quite small. We expect the magnitude of improvements in farm productivity and household wealth will increase as trees mature, as all of the qualitative data collected supports this trend. Future studies of this area would need to confirm such an assertion. These conclusions underline the need to provide agroforestry techniques in collaboration with other development initiatives that can deliver short-term benefits to farmers while waiting for the investments in trees to pay off.

We approached our research with an understanding that agroforestry practices may be used and perceived differently by men and women [45]. However, we did not find that women participated in agroforestry in a substantially different way, as all farmers reported planting, tending to and harvesting from trees. The one gender difference we observed was that women were primarily responsible for fuel wood collection and thus ranked fuel wood collection as a more significant benefit than men did.

Our study was particular to a specific agroforestry project and location, allowing us to deeply understand the unique context of these communities [46,47]. However, we feel that the conclusions can still provide significant guidance to future studies on reducing farmers' vulnerability to climate-related hazards. Our findings suggest that it is likely that for extremely poor households, improving general well-being will be the most effective way to reduce vulnerability to future hazards associated with climate change. This finding can be generalized to other subsistence farming communities, as the most basic problems faced by farmers during climate-related hazards are widespread. Whether this finding can be applied to more successful small-scale farmers remains to be explored.

Finally, we found that fully engaging farmers in the research process significantly improved our analysis. Farmers report benefiting from the research process because it provided them with an opportunity to discuss constraints to their well-being and think about potential solutions. Communities found that discussions of vulnerability allowed them to reflect on their current farming practices and engage in a community conversation of future adaptation options. This dialogue really flourished when we presented our initial findings to the farmers in a community gathering we organized at the end of our field research. This conclusion supports White's assertion that encouraging reflection among communities is of value in and of itself [47].

Discussions with farmers at this community gathering stressed the responsibility field researchers have to provide feedback and results to the participants in their study. As the local chief explained, 'Many scientists have come here, but you are the first to return with results'. We hope that future studies can continue to build on this approach and engage farmers more fully throughout the research process. This will allow the scientific community to further the dialogue with farmers in how we can work together to ensure environmental sustainability and well-being improvements in the face of future climate-related hazards.

\section{Conclusions}

Our findings show that farmers are interested in improvements in their food security, income, farm productivity, and environmental sustainability of their farms in the face of outside shocks and hazards. Our results agree with the literature in calling for a focus on reducing vulnerability to climate-related hazards through robust adaptation measures that can be beneficial regardless of the type of climate hazard experienced. From analysis of current coping strategies being employed, it is clear that subsistence farmers in the Nyando District are not coping with climate-related hazards in a sustainable way. As climate change increases the frequency and intensity of these events, existing coping strategies may no longer be able to support households through difficult times.

Even in a short-term analysis of a farmer-managed agroforestry study with low uptake of intensive techniques, agroforestry practices provided farmers noticeable 
benefits. Involvement in agroforestry improved farm productivity, household wealth, increased income diversity, reduced soil erosion and provided a number of specific coping strategies to help households during exposure to climate-related hazards.

These conclusions beg the question, what can be achieved with even more effective implementation of agroforestry practices? In order to enhance the effectiveness of agroforestry in improving farmer well-being in the face of climate-related hazards, our findings suggest the following for future agroforestry development projects:

\section{Pair agriculture and agroforestry training}

Agroforestry is a long-term process and, as we showed in this analysis, benefits can take a long time to accrue. Therefore, improving the sustainability of agroforestry projects is key. It will be important to include shorterterm benefits to farmers that are coupled with agroforestry implementations so farmers do not get discouraged during the initial project stages.

Pairing agroforestry and agricultural training is an excellent opportunity to provide short-term benefits from improving basic agriculture knowledge with long-term extension for agroforestry practices. We also found that if farmers understand the potential of their trees to enhance their well-being, they put more concentrated efforts toward tree care and management, giving further reason to focus on the training aspect of agroforestry programs.

\section{Improve market accessibility to enhance income- generating opportunities provided by agroforestry techniques}

As our analysis showed, one of the most effective ways to reduce farmers' vulnerability to climate change is through improving incomes of farmers. Because tree crops are more resistant to climatic shocks, they can provide support for farmers during these times of stress. Agroforestry techniques have the potential to provide income to farmers through the sale of fuel wood, timber, fruit and seedlings. In comparing the benefits derived from agroforestry involvement across the two sublocations, market access played a key role in improving household incomes due to agroforestry projects. Therefore, market access needs to be improved. This can be done on a governmental scale through improving infrastructure or, more locally, through establishing cooperatives that pool resources to access markets.

\section{Couple access to farm implements and capital with agroforestry projects}

Lack of access to farm implements and capital were listed as key constraints to overall farm productivity in the Nyando region, and almost no one has access to small-scale loans in this area. Although not directly related to agroforestry, any major constraint to farm productivity reduces farmers' ability to cope with climate change. In addition, by improving access to loans and to farm implements through an agroforestry development project, farmers are able to see tangible benefits in the short term from their project involvement before their trees have matured. The coupling of access to credit and agroforestry training has been found to be an effective way to reduce vulnerability to climate change in other studies [4]. Access to weather index insurance may be another support mechanism worth exploring to couple with future agroforestry development projects.

\section{Organize educational farm visits to successful agroforestry projects to increase adoption of agroforestry techniques}

There is substantial room for the expanded use of agroforestry techniques in improving farm productivity, as adoption of intensive agroforestry techniques was low among farmers. The key reason for this low adoption rate was that farmers perceive these techniques to be high risk. All farmers interviewed who engaged in intensive agroforestry techniques had seen the benefits on someone else's farm before implementing the techniques themselves. Many farmers suggested this as the most effective way to convince them that agroforestry techniques may be useful in their area.

\section{Concluding remarks}

Agroforestry, like any single coping strategy, will not prove to be the silver bullet to climate change adaptation. However, we found that agroforestry practices do have substantial potential to help farmers improve their well-being and the environmental sustainability of their farms. Through these improvements, and by providing some additional specific adaptation strategies, agroforestry practices can reduce farmer vulnerability to climate change. By adopting the recommendations outlined above, we hope that future agroforestry projects can contribute, as a part of larger development initiatives, to helping subsistence farmers better adapt to future climate change.

\section{Competing interests}

The authors declare that they have no competing interests.

\section{Authors' contributions}

TT conceived the study design, collected field data, analyzed results and drafted the manuscript. HN participated in the study design, contributed to the draft of the manuscript and performed critical reviews. Both authors read and approved the final manuscript.

Authors' information

TT was lead author.

\section{Acknowledgements}

First and foremost, we would like to thank the individual farmers for their participation throughout the research process. We also immensely grateful 
to Walter Adongo, Joash Mango, Amos Odhiambo and Brian Mateche for their integral work as members of the research team. This research would not have been possible without the support of the Comart Foundation and the Harvard University Weatherhead Center. Finally, a special thanks to William Clark and Andrew Harris, for their insights and constructive feedback.

\section{Author details}

${ }^{1}$ Sustainability Science Program, Harvard University, Cambridge, MA, USA.

${ }^{2}$ World Agroforestry Centre (ICRAF), Nairobi, Kenya. ${ }^{3}$ CGIAR Research Program on Climate Change, Agriculture and Food Security (CCAFS).

Received: 24 May 2012 Accepted: 14 August 2012

Published: 2 October 2012

\section{References}

1. Alley R, Berntsen T, Bindoff N, Chen Z, Chidthaisong A: Solomon S, Qin D, Manning M. In Climate Change 2007: The Physical Science Basis. Contribution of Working Group I to the 4th Assessment Report of the Intergovernmental Panel on Climate Change. Cambridge, UK: Cambridge University Press; 2007.

2. Nelson GC, Rosegrant MW, Koo J, Robertson R, Sulser T, Zhu T, Ringler C: Climate Change: Impact on Agriculture and Costs of Adaptation. Washington DC: IFPRI; 2009.

3. Thompson J, Millstone E, Scoones I, Ely A, Marshall F: Agri-food System Dynamics: Pathways to Sustainability in an Era of Uncertainty, STEPS Center Working Paper 4. Brighton, UK: STEPS Center; 2007.

4. Gabrielsson S, Brogaard S, Jerneck A: Living without buffers: illustrating climate vulnerability in the Lake Victoria Basin. In Uncertain futures. PhD thesis:: Lund University, Centre for Sustainability Studies; 2012.

5. Morton J: The impact of climate change on smallholder and subsistence agriculture. Proc Natl Acad Sci U S A 2007, 104:19680-19685.

6. Kates RW: Cautionary tales: adaptation and the global poor. Climate Change 2000, 45:5-17.

7. Smit B: Adaptation, adaptive capacity and vulnerability. Glob Environ Chang 2006, 16:282-292.

8. Challinor A, Wheeler T, Garforth C, Craufurd P, Kassam A: Assessing the vulnerability of food crop systems in Africa to climate change. Climate Change 2007, 83:381-399.

9. Verchot LV, Noordwijk MV, Kandji S, Tomich T, Ong C, Albrecht A, Mackensen J, Bantilan C, Anupama K, Palm C: Climate change: linking adaptation and mitigation through agroforestry. Mitig Adapt Strat Glob Chang 2007, 12:901-918.

10. Bank W: World Development Report 2008: Agriculture and Development. Washington DC: World Bank Publications; 2008.

11. Garrity D: Science based agroforestry and the achievement of the millennium development goals. In World Sgroforestry into the Future. Edited by Garrity D, Okono A, Grayson M, Parrott S. Nairobi, Kenya: World Agroforestry Centre; 2006.

12. Leakey R: Agroforestry: a delivery mechanism for multi-functional agriculture. In Handbook on Agroforestry: Management Practices and Environmental Impact. Edited by Kellimore LR. New York, NY: Nova Science Publishers; 2010:461-471.

13. Scherr SJ, Franzel S: Introduction. In Trees on the Farm: Assessing the Adoption Potential of Agroforestry Practices in Africa. Edited by Franzel S, Scherr SJ. New York, NY: Cabi Publishing; 2002.

14. Scherr SJ, Franzel S: Promoting new agroforestry technologies: policy lessons from on-farm research. In Trees on the Farm: Assessing the Adoption Potential of Agroforestry Practices in Africa. Edited by Franzel S, Scherr SJ. New York, NY: Cabi Publishing; 2002.

15. Turner BL, Kasperson RE, Matson PA, McCarthy J, Corell R, Christensen L: A framework for vulnerability analysis in sustainability science. Proc Natl Acad Sci U S A 2003, 100:8074-8079.

16. Place $F$, Adato $M$, Hebinck $P$ : Understanding rural poverty and investment in agriculture: an assessment of integrated quantitative and qualitative research in western Kenya. World Dev 2007, 35:312-325.

17. Kenya Food Security Steering Group: Food security district profile, Nyando District, Nyanza Province. http://www.nyando.org/reference/foodsecurity.pdf.

18. Thorlakson T: Reducing Subsistence Farmers' Vulnerability to Climate Change: The Potential Contributions of Agroforestry in Western Kenya. World Agroforestry Centre Occasional Paper 16. Nairobi, Kenya: World Agroforestry Centre; 2011.
19. Shipton PM: Mortgaging the Ancestors: Ideologies of Attachment in Africa. New Haven, CT: Yale University Press; 2009.

20. Okoba BO, Graaff J: Farmers' knowledge and perceptions of soil erosion and conservation measures in the Central Highlands, Kenya. Land Degrad Develop 2005, 16:475-487.

21. Kuyah S, Dietz J, Muthuri C, Jamnadass R, Mwangi P, Coe R, Neufeldt H: Allometric equations for estimating biomass in agricultural landscapes: I. Aboveground biomass. Agric Ecosyst Environ 2012, 158:216-224.

22. Rosenbaum PR, Rubin DB: Constructing a control group using multivariate matched sampling methods that incorporate the propensity score. Am Stat 1985, 39:33-38.

23. Ho D, Imai K, King G, Stuart E: Matching as non-parametric preprocessing for reducing model dependence in para-metric causal inference. Polit Anal 2007, 15:199-236.

24. Kabubo-Mariara J, Linderhof VGM, Kruseman G, Atieno R, Mwabu G: Household Welfare, Investment in Soil and Water Conservation and Tenure Security: Evidence from Kenya. Amsterdam, Netherlands: Poverty Reduction and Environmental Management, Working Paper No 06/06; 2006.

25. Imai K: Toward a common framework for statistical analysis and development. J Comput Graph Stat 2008, 17:892-913.

26. Weiss RS: Learning from Strangers: The Art and Method of Qualitative Interview Studies. New York, NY: The Free Press; 1994.

27. Kenya Red Cross: Drought operations update: alleviating human suffering. No. 1/09. http://reliefweb.int/sites/reliefweb.int/files/resources/ FE8B12A7BF328277C125764000435C 92-Full_Report.pdf.

28. Office for the Coordination of Humanitarian Affairs (OCHA): Kenya: 2010 floods and landslides situation update. Report number 3. http://reliefweb.int/ sites/reliefweb.int/files/resources/D86F059443444C20C1257726003F27 7DFull_Report.pdf.

29. Costanza R, Fisher B, Ali S, Beer C, Bond L, Boumans R, Danigelis NL, Dickinson J, Elliott C, Farley J, Gayer DE, MacDonald Glenn L, Hudspeth J: Quality of life: an approach integrating opportunities, human needs, and subjective well-being. Ecol Econ 2007, 61:267-276.

30. Chambers R, Conway GR: Sustainable Rural Livelihoods: Practical Concepts for the 21st Century. Brighton, UK: Institute of Development Studies Discussion Paper 296; 1991.

31. Lindenberg M: Measuring household livelihood security at the family and community level in the developing world. World Dev 2002, 30:301-318

32. White S: Analysing wellbeing: a framework for development practice. Dev Pract 2010, 20:158-172.

33. Appadurai $\mathrm{A}$ : The capacity to aspire: culture and the terms of recognition. In Culture and Public Action. Edited by Rao V, Walton M. Palo Alto, CA: Stanford University Press; 2004

34. Kristjanson P, Neufeldt H, Gassner A, Mango J, Kyazze FB, Desta S, Sayula G, Thiede B, Förch W, Thornton PK, Coe R: Are food insecure smallholder households making changes in their farming practices? Evidence from East Africa. Food Sec 2012, 4:381-397.

35. Mogaaka H: Climate Variability and Water Resources Degradation in Kenya: Improving Water Resources. Washington, DC: World Bank Working Paper No $69 ; 2006$.

36. Eriksen SH, Brown K, Kelly PM: The dynamics of vulnerability: locating coping strategies in Kenya and Tanzania. Geogr J 2005, 171:287-305.

37. Nelson GC: Food Security, Farming, and climate change to 2050. Washington DC: International Food Policy Research Institute; 2010.

38. Brooks N, Adger W, Kelly P: The determinants of vulnerability and adaptive capacity at the national level and implications for adaptation. Glob Environ Chang 2005, 15:151-163.

39. Smit B, Pilifosava O: Adaptation to climate change in the context of sustainable development and equity. Sustain Dev 2003, 8:879-906.

40. Ahmed S, Chaturvedi S, Saroch E, Chopde S, Sharma S, Dixit A, Gyawali D: Singh Rathore M, Mudrakartha S, Moench M, Rehman T, Wajih SA, Upadhya M, Sharma RK: Adaptive Capacity and Livelihood Resilience: Adaptive Strategies for Responding to Floods and Droughts in South Asia. Boulder, CO: The Institute for Social and Environmental Transition; 2004.

41. Krysanova V, Buiteveld H, Haase D, Hattermann FF, Niekerk K, Roest K, Martínez-Santos P, Schlüter M: Practices and lessons learned in coping with climatic hazards at the river-basin scale: Floods and droughts. Ecol Soc 2008, 13:1-27. 
42. Smucker TA, Wisner B: Changing household responses to drought in Tharaka, Kenya: vulnerability, persistence and challenges. Disasters 2008 , 32:190-215

43. Adger W, Arnell N, Tompkins E: Successful adaptation to climate change across scales. Glob Environ Chang 2005, 15:77-86.

44. Syampungani S, Chirwa PW, Akinnifesi FK, Ajayi OC: The potential of using agroforestry as a win-win solution to climate change mitigation and adaptation and meeting food security challenges in southern Africa. Agric J 2010, 5:80-88.

45. Kiptot E, Franzel S: Gender and agroforestry in Africa: a review of women's participation. Agrofor Syst 2012, 84:35-58.

46. Gabrielsson S: Uncertain futures. PhD thesis. Lund University, Centre for Sustainability Studies; 2012

47. White S: Bringing Wellbeing into Development Practice. Wellbeing in Developing Countries Research Group Working Paper. Bath, UK: University of Bath; 2009.

doi:10.1186/2048-7010-1-15

Cite this article as: Thorlakson and Neufeldt: Reducing subsistence farmers' vulnerability to climate change: evaluating the potential contributions of agroforestry in western Kenya. Agriculture \& Food Security 2012 1:15.

\section{Submit your next manuscript to BioMed Central and take full advantage of:}

- Convenient online submission

- Thorough peer review

- No space constraints or color figure charges

- Immediate publication on acceptance

- Inclusion in PubMed, CAS, Scopus and Google Scholar

- Research which is freely available for redistribution 